\title{
COMPARATIVE STUDIES OF RUMINAL FLUID \\ COLLECTED BY ORAL TUBE OR BY PUNCTURE OF THE CAUDOVENTRAL RUMINAL SAC
}

\author{
B. HOFÍREK, D. HAAS \\ Clinic of Diseases of Ruminants, Faculty of Veterinary Medicine, University of Veterinary and Pharmaceutical \\ Sciences, Brno, Czech Republic \\ Received April 4, 2000 \\ Accepted February 7, 2001
}

\section{Abstract}

Hofírek B., D. Haas: Comparative Studies of Ruminal Fluid Collected by Oral Tube or by Puncture of the Caudoventral Ruminal Sac. Acta Vet. Brno 2001, 70: 27-33.

Samples of ruminal fluid were collected in four groups of high-producing dairy cows simultaneously by an oral probe and by percutaneous puncture of the caudoventral ruminal sac. The samples were tested for basic indicators of the metabolic profile including $\mathrm{pH}$, total acidity, ammonia, infusoria counts, and total and relative amounts of volatile fatty acids. Significant differences $(P<0.05)$ between the samples collected by oral probe $(0)$ and by puncture $(\mathrm{p})$ were observed for $\mathrm{pH}(\mathrm{o}-6.74 \mathrm{vs} . \mathrm{p}-6.23)$, total acidity (o - $17.1 \mathrm{vs} . \mathrm{p}-24.7)$, and total VFA (o - 101.18 vs. $\mathrm{p}-131.70 \mathrm{mmol} / \mathrm{l})$ in the group of cows with mean daily production of 181 of milk. Highly significant $(P<0.01)$ differences between the samples collected by oral probe and by puncture were observed in the groups yielding daily 24 and 381 of milk for $\mathrm{pH}(\mathrm{o}-6.95 \mathrm{vs}$. $\mathrm{p}-6.24$ and $\mathrm{o}-7.00 \mathrm{vs}$. 6.21, respectively), total acidity (o-13.2 vs. p - 22.2 and o - $12.6 v s . \mathrm{p}-25.2$, respectively), and total VFA (o - 99.23 vs. p - $136.25 \mathrm{mmol} / \mathrm{l}$ and o - 89.66 vs. p - $140.14 \mathrm{mmol} / \mathrm{l}$, respectively). Buffering of the ration for the cows yielding 381 of milk per day with $200 \mathrm{~g}$ of sodium hydrogen carbonate increased the above differences in $\mathrm{pH}$, total acidity, and total VFA. Ruminal fluid samples collected by percutaneous puncture of the caudoventral ruminal sac better indicate the intensity of ruminal fermentation processes apparently because their composition is not influenced by the amount of saliva or buffer which is variable in the content of the cranial ruminal sacs where the oral samples are collected from. Although the sampling of ruminal fluid by percutaneous puncture is an easy method, it can be associated with some complications. Their risk can be minimised by strict adherence to the recommended procedure and observation of rules of aseptic work.

Cattle, sampling methods, pH, total acidity, ammonia, infusoria, VFA

Samples of ruminal fluid have been collected for diagnostic, therapeutic, and scientific purposes since the mid of the past century. Their examination has become a part of routine diagnostics of clinical and particularly subclinical forestomachal disorders (Pounden 1954; Hofírek et al. 1976; Dirksen 1981; Dvořák et al. 1997).

In the recent years, ruminal fluid tests have been used also for the control of nutrition and checks of ruminal fermentation in high-yielding dairy cows to obtain data for the elaboration of preventive measures against metabolic disorders and production diseases. Many factors must be considered in the calculation of daily rations and attempts to attain the optimal intensity of ruminal fermentation are not always fully successful owing to very complex interaction among the individual ration constituents.

The composition of the ruminal fluid is very variable, depending on the sampling site and method and the intensity of ruminal fermentation. The latter factor is particularly important in herds where total mixture rations (TMR) are fed. To assess the results of the metabolic profile test of ruminal fluid correctly it is necessary to obtain standard samples even on repeated collections. This necessity has been encouraging attempts to improve the existing ruminal fluid sampling techniques. An alternative to the conventional oral tube method 
(Serensen and Schambye 1955; Slanina 1967; Hofírek 1970; Dirksen 1975; Lebeda et al. 1981; Dvořák et al. 1997) combined with the use of various appliances is direct collection from the caudal ruminal sac using a needle run through the abdominal and ruminal walls (Hollberg 1984; Polack and Perrin 1998; Brugère et al. 1990).

The objective of this study was to compare the methods of oral tube collection and direct collection of ruminal fluid from the caudoventral ruminal sac.

\section{Materials and Methods}

Animals

The samples were collected in four herds differing in average milk yields always three to four hours after feeding. Group 1 (Table 1).

Five Bohemian Red Pied dairy cows of a herd with average daily milk yield of 181 . The cows were fed conventionally twice a day with hay and silage; concentrates were dosed according to individual milk yield. Group 2 (Table 2).

Five Holstein dairy cows of a herd with average daily milk yield of 181 . The cows received the total mixture ration (TMR) twice a day. Group 3 (Table 3 ).

Eight Holstein dairy cows of a herd with average daily milk yield of 241 . The cows received TMR buffered with sodium bicarbonate (139 g/animal/day) twice a day. Group 4 (Table 4).

Eleven Holstein dairy cows of a herd with average daily milk yield of 381 . The cows received TMR buffered with sodium bicarbonate ( $200 \mathrm{~g} / \mathrm{animal} /$ day) three times a day.

Ruminal fluid sampling

First the direct sampling method was used. The puncture site on a horizontal line connecting the pregenual skin fold with the last rib was clipped and disinfected. Then abdominal and ruminal walls were punctured with a 90mm-long $1.5 \mathrm{~mm}$ gauge epidural needle with mandrin (Hofírek and Haas, 2000) and a sample was taken. Oral tube was run and another sample was taken immediately thereafter (Dvořák et al. 1997) to minimise possible error due to lag. The technique described by Sorensen and Schambye (1955) was used. Altogether $29+29$ samples of ruminal fluid were collected. The sample volume required for the analyses done in our experiments was 20 to $30 \mathrm{ml}$.

The following characteristics of the ruminal fluid metabolic profile were tested: $\mathrm{pH}$, total acidity, infusoria count, and concentrations of ammonia and total and individual volatile fatty acids (VFA). Significance of differences was assessed by the paired $t$-test. The puncture site and the general state of health were monitored for several weeks after the sampling.

Table 1

Characteristics of ruminal fluid collected by oral tube and by ruminal puncture.

Group 1, Bohemian Red Pied, $\mathrm{n}=5$, average milk yield 181, fed hay, silage, and concentrates.

\begin{tabular}{|l|l|l|l|l|l|}
\hline \multirow{2}{*}{ Characteristic } & \multicolumn{2}{|l|}{$\mathrm{a}$} & $\mathrm{b}$ & \multirow{2}{*}{$P$} \\
\cline { 2 - 5 } & Mean & \pm S. D. & Mean & \pm S. D. & \multirow{2}{*}{$*$} \\
\hline $\mathrm{pH}$ & 6.74 & \pm 0.188 & 6.23 & \pm 0.400 & $*$ \\
\hline Total acidity [arbitrary units] & 17.1 & \pm 2.15 & 24.7 & \pm 6.79 & $*$ \\
\hline Ammonia [mmol/1] & 6.5 & \pm 2.01 & 7.4 & \pm 2.96 & N.S. \\
\hline Infusoria [103/ml] & 302400 & \pm 176218 & 241.600 & \pm 129293 & N.S. \\
\hline VFA [mmol/1] & 101.18 & \pm 13.36 & 131.70 & \pm 17.73 & $*$ \\
\hline Acetic acid [\%] & 63.2 & \pm 1.18 & 63.0 & \pm 1.45 & N.S. \\
\hline Propionic acid [\%] & 20.5 & \pm 3.97 & 20.7 & \pm 4.30 & N.S. \\
\hline Isobutyric acid [\%] & 0.6 & \pm 0.16 & 0.6 & \pm 0.08 & N.S. \\
\hline Butyric acid [\%] & 13.4 & \pm 2.78 & 13.4 & \pm 2.78 & N.S. \\
\hline Isovaleric acid [\%] & 1.2 & \pm 0.63 & 1.1 & \pm 0.56 & N.S. \\
\hline Valeric acid [\%] & 1.1 & \pm 0.26 & 1.2 & \pm 0.24 & N.S. \\
\hline
\end{tabular}

Legends: a - oral probe

$\mathrm{b}$ - puncture

* $P \leq 0.05$

$* * P \leq 0.01$ 
Analyses

Immediately after collection, the samples were filtered through a sieve to remove large particles and divided into portions. The analyses were done instantly or the portions were frozen (except for those intended for protozoa enumeration). The following agents were used for sample preservation: mercury chloride (approx. 2 drops per tube) for the determination of $\mathrm{pH}$, total acidity, and lactic acid and ammonia concentrations; chloroform ( 2 drops per tube) for analyses of VFA; $10 \%$ formaldehyde solution ( $1 \mathrm{ml}$ per $4 \mathrm{ml}$ of sample) for enumeration of protozoa.

$\mathrm{pH}$

pH was measured with the PHM 64 Research pH Meter (Radiometer Copenhagen) using the pH $7.00 \pm 0.01$ buffer supplied by the manufacturer as the calibration standard.

Total acidity

The method described by Jonov et al. (1957) was used. Ten millilitres of sample was titrated with $0.1 \mathrm{M}$ sodium

Table 2

Characteristics of ruminal fluid collected by oral tube and by ruminal puncture. Group 2, Holstein dairy cows, $\mathrm{n}=5$, average milk yield 18 , fed unbuffered TMR.

\begin{tabular}{|c|c|c|c|c|c|}
\hline \multirow{2}{*}{ Characteristic } & \multicolumn{2}{|l|}{$\mathrm{a}$} & \multicolumn{2}{|l|}{$\mathrm{b}$} & \multirow{2}{*}{$P$} \\
\hline & Mean & \pm S. D. & Mean & \pm S. D. & \\
\hline $\mathrm{pH}$ & 6.89 & \pm 0.187 & 6.08 & \pm 0.268 & $*$ \\
\hline Total acidity [arbitrary units] & 17.1 & \pm 3.73 & 28.2 & \pm 10.37 & N.S. \\
\hline Ammonia [mmol/l] & 6.9 & \pm 1.14 & 7.8 & \pm 1.43 & N.S. \\
\hline Infusoria [103/ml] & 276800 & \pm 107420 & 251200 & \pm 48530 & N.S. \\
\hline VFA $[\mathrm{mmol} / \mathrm{l}]$ & 88.48 & \pm 7.38 & 138.16 & \pm 20.96 & $* *$ \\
\hline Acetic acid [\%] & 58.9 & \pm 4.08 & 58.9 & \pm 4.29 & N.S. \\
\hline Propionic acid [\%] & 21.7 & \pm 5.20 & 21.8 & \pm 5.07 & N.S. \\
\hline Isobutyric acid [\%] & 0.8 & \pm 0.11 & 0.6 & \pm 0.11 & N.S. \\
\hline Butyric acid [\%] & 16.3 & \pm 2.42 & 16.4 & \pm 2.31 & N.S. \\
\hline Isovaleric acid [\%] & 1.1 & \pm 0.17 & 1.1 & \pm 0.17 & N.S. \\
\hline Valeric acid [\%] & 1.2 & \pm 0.32 & 1.3 & \pm 0.43 & N.S. \\
\hline
\end{tabular}

For legends see Table 1

Table 3

Characteristics of ruminal fluid collected with oral tube and by ruminal puncture.

Group 3, Holstein, $\mathrm{n}=8$, average milk yield 24 1, fed TMR buffered with sodium bicarbonate (139g/animal/day).

\begin{tabular}{|l|l|l|l|l|l|}
\hline \multirow{2}{*}{ Characteristic } & \multicolumn{2}{|l|}{ A } & \multicolumn{1}{l|}{ b } & \multirow{2}{*}{$P$} \\
\cline { 2 - 5 } & Mean & \pm S. D. & Mean & \pm S. D. & \\
\hline pH & 6.95 & \pm 0.168 & 6.24 & \pm 0.271 & $* *$ \\
\hline Total acidity [arbitrary units] & 13.2 & \pm 3.13 & 22.2 & \pm 4.72 & $* *$ \\
\hline Ammonia [mmol/1] & 7.8 & \pm 1.35 & 7.6 & \pm 1.69 & \multirow{2}{*}{ N.S. } \\
\hline Infusoria [103/ml] & 432000 & \pm 11.056 & 387000 & \pm 87629 & N.S. \\
\hline VFA [mmol/1] & 99.23 & \pm 18.40 & 136.25 & \pm 8.95 & $*$ \\
\hline Acetic acid [\%] & 62.1 & \pm 3.83 & 62.7 & \pm 0.94 & N.S. \\
\hline Propionic acid [\%] & 20.7 & \pm 4.06 & 19.8 & \pm 1.76 & N.S. \\
\hline Isobutyric acid [\%] & 0.7 & \pm 0.14 & 0.7 & \pm 0.11 & N.S. \\
\hline Butyric acid [\%] & 14.3 & \pm 1.44 & 14.3 & \pm 1.78 & N.S. \\
\hline Isovaleric acid [\%] & 1.0 & \pm 0.23 & 1.1 & \pm 0.34 & N.S. \\
\hline Valeric acid [\%] & 1.2 & \pm 0.20 & 1.4 & \pm 0.20 & $* *$ \\
\hline
\end{tabular}

For legends see Table 1 
Table 4

Characteristics of ruminal fluid collected by oral tube and by ruminal puncture.

Group 4, Holstein, $\mathrm{n}=11$, average milk yield 38 1, fed TMR buffered with sodium bicarbonate (200 g/animal/day).

\begin{tabular}{|l|l|l|l|l|l|}
\hline \multirow{2}{*}{ Characteristic } & \multicolumn{2}{|l|}{$\mathrm{a}$} & \multicolumn{2}{l|}{$\mathrm{b}$} & \multirow{2}{*}{$P$} \\
\cline { 2 - 5 } & Mean & \pm S. D. & Mean & \pm S. D. & \\
\hline PH & 7.00 & \pm 0.63 & 6.21 & \pm 0.276 & $* *$ \\
\hline Total acidity [arbitrary units] & 12.6 & \pm 3.40 & 25.2 & \pm 6.71 & $* *$ \\
\hline Ammonia [mmol/1] & 11.3 & \pm 6.57 & 10.0 & \pm 3.57 & N.S. \\
\hline Infusoria [103/ml] & 394909 & \pm 75833 & 408727 & \pm 52271 & N.S. \\
\hline VFA [mmol/1] & 89.66 & \pm 14.54 & 140.14 & \pm 11.97 & $* *$ \\
\hline Acetic acid [\%] & 59.8 & \pm 2.88 & 59.3 & \pm 3.01 & $*$ \\
\hline Propionic acid [\%] & 23.1 & \pm 4.03 & 23.9 & \pm 4.67 & $*$ \\
\hline Isobutyric acid [\%] & 0.8 & \pm 0.15 & 0.6 & \pm 0.13 & $* *$ \\
\hline Butyric acid [\%] & 13.9 & \pm 1.92 & 13.7 & \pm 2.09 & N.S. \\
\hline Isovaleric acid [\%] & 1.2 & \pm 0.15 & 1.2 & \pm 0.18 & N.S. \\
\hline Valeric acid [\%] & 1.2 & \pm 0.18 & 1.3 & \pm 0.20 & $* *$ \\
\hline
\end{tabular}

For legends see Table 1

Table 5

$\mathrm{pH}$ of ruminal fluid samples collected by ruminal puncture or by oral tube

\begin{tabular}{|l|c|c|}
\hline Author & Ruminal puncture & Oral tube \\
\hline Hollberg (1984) & $6.53 \pm 0.59$ & $6.89 \pm 0.46$ \\
\hline Rousseau et al. (1989) & $6.27 \pm 0.70$ & $7.31 \pm 0.47$ \\
\hline Brugère et al. (1990) & $6.20 \pm 0.52$ & $7.17 \pm 0.51$ \\
\hline Hofírek and Haas (2000) & $6.18 \pm 0.38$ & $6.90 \pm 0.20$ \\
\hline
\end{tabular}

hydroxide with $\mathrm{pH} 8.5$ as the endpoint using a $\mathrm{pH}$ meter or an automatic titrator. The amount of sodium hydroxide necessary for this $\mathrm{pH}$ shift was proportional to the total acidity value.

\section{Ammonia}

Ammonia concentration was determined by the method described in detail by Zapletal and Hofírek (1971); the method is based on diffusion of ammonia in Conway dishes induced with saturated potassium carbonate solution, and subsequent titration with $0.01 \mathrm{M}$ hydrochloric acid using methyl red as the indicator.

Ruminal protozoa enumertation

After filtration, the sample was thoroughly mixed and preserved by adding $1 \mathrm{ml}$ of $10 \%$ formaldehyde to $4 \mathrm{ml}$ of sample. The preserved samples were stored at $4{ }^{\circ} \mathrm{C}$. The total protozoa number was established using the FuchsRosenthal chamber. After mixing with $0.1 \%$ solution of methylene blue at the ratio of $1: 20$, the sample was applied into the chamber and all protozoa in all fields were enumerated. The obtained value was corrected to $1 \mathrm{ml}$ of sample by multiplying the reading by 320 (chamber index) and 20 (dilution index).

Volatile fatty acids

VFA were determined by GC (Cottyn et al. 1968). Proteins present in the sample were precipitated by addition of $25 \%$ metaphosphoric acid and the "ghost effect" was eliminated by addition of $5 \%$ formic acid. Clear sample supernatant obtained by centrifugation was injected into the column directly. Standard solutions were used to calculate the concentrations of the individual VFA.

Chromatography conditions

Chromatograph Chrom 5. (Laboratory Instruments, Prague) flame ionisation detector; glass column $3.5 \mathrm{~mm} x$ 1.2; packing Porapak P (Sulpeco), 80 - 100 mesh, wetting with 3\% HPO; column, injector and detector temperature $170{ }^{\circ} \mathrm{C}$ carrying gas nitrogen, $1.2 \mathrm{kp} / \mathrm{cm}^{2}$ hydrogen flow rate $0.3 \mathrm{ml} / \mathrm{min}$ air flow rate $600 \mathrm{ml} / \mathrm{min}$; injection volume $0.6 \mu 1$. 


\section{Results}

The results are shown in Tables I through IV.

Significant within-group differences in several characteristics were found in all the groups. $\mathrm{pH}$ of ruminal fluid collected by puncture was significantly $(P \leq 0.05)$ or highly significantly $(P \leq 0.01)$ lower in all the 29 tested samples, of all the four groups, the differences ranging from 0.51 to 0.81 units. Greater differences were found in high-yielding cows fed buffered TMR.

A similar difference was observed in titration acidity. Again, all the within-group differences were significant or highly significant, the differences ranging from 12.6 to 7.6 arbitrary units. The difference was greater in the cows fed TMR and the maximum difference was found in Group 4, i.e. in high-yielding cows fed TMR buffered with $200 \mathrm{~g}$ sodium hydrogen carbonate per animal per day (Table 4).

Another characteristic showing significant or highly significant within-group differences was the concentration of total VFA. The differences ranged from 30.52 to $50.48 \mathrm{mmol} / \mathrm{l}$. The greatest difference was again found in Group 4, i.e. in high-yielding cows fed TMR buffered with $200 \mathrm{~g}$ sodium hydrogen carbonate per animal per day.

Differences in concentrations of the individual VFA were found rather exceptionally. Since they were observed only in some acids in Group 4, showing the highest milk yield (Table 4).

\section{Discussion}

The conventional method of ruminal fluid sampling with an oral tube has been in the recent years completed by a direct method consisting in direct puncture of the ruminal wall. The first to assess this surgical method of ruminal fluid sampling was Hollberg (1984) who described the technique, pointed out complications that may develop, and compared compositions of samples collected by the conventional method and by puncture. For the collection by puncture he used a $2.4 \mathrm{~mm}$ gauge $150-\mathrm{mm}$-long needle run deeply into rumen. Through this needle another thin, blunt and somewhat longer needle with side holes at its end was run and the sample was aspirated with a 200-ml syringe. The puncture site was on the horizontal line connecting stifle joint with the last rib. Inflammatory thickening of the abdominal wall was found in up to one half of the cows slaughtered within $24 \mathrm{~h}$ and in up to two thirds of those slaughtered within six days. Adhesive peritonitis was observed sporadically. Significant differences between the samples collected by the conventional method and by puncture were found in $\mathrm{pH}$, results of the methylene blue test and concentrations of total and individual VFA. Owing to these results and the risk of complications, Hollberg was rather cautious in assessing the expedience of the puncture method.

Rousseau et al. (1989) and and Perrin (1989) used a 120-mm-long $3.5 \mathrm{~mm}$ gauge trocar with mandrin and a probe for direct ruminal fluid sampling. To facilitate its penetration, the trocar was run through a skin incision made with a scalpel in the left paralumbar fossa. Then the mandrin was replaced by a metallic $35-\mathrm{mm}$ long probe run into the rumen down to the level of the caudoventral sac. After sample aspiration, first the probe and then the trocar are removed. The trocar was rinsed with ethanol upon removal to minimise the risk of local peritonitis. Although the authors mention possible complications, they do not emphasise this hazard too much.

Brugère et al. (1990) substantiated the use of the direct sample collection method by pragmatic reasons casting doubt on the value of orally collected samples for the assessment of the individual ruminal fermentation processes. They used a $3 \mathrm{~mm}$ gauge trocar, a $2.5 \mathrm{~mm}$ gauge probe with side holes, and a syringe. In their opinion, complications can be avoided if rules of aseptic work are adhered to.

Our experiments were done using the relatively thin $1.5 \mathrm{~mm}$ gauge epidural needle with a mandrin to minimise the injury to the abdominal and ruminal walls and thus the risk of 
infection that may result in peritonitis. Epidural $2.2 \mathrm{~mm}$ gauge needles with mandrins can be used for this purpose without increasing the risk as well, but, in our opinion, the use of 3 to $3.5 \mathrm{~mm}$ gauge trocars can be associated with more severe complications. Needles with a smaller gauge cannot be recommended because they are prone to impaction by solid particles present in the ruminal fluid.

As shown by our results, complications as a consequence of abdominal puncture cannot be wholly precluded. However, their rise is only exceptional if rules of good surgical practice, including clipping, shaving and disinfection of the puncture site, effective sterilisation of the injection needle, and careful disinfection of the site after its removal, are strictly observed. The risk of injury to the uterus due to abdominal puncture at the level of the stifle joint in high-pregnant cows was not pointed out by any of the above authors. It can be prevented by clinical examination, balotment, and cranial shifting of the puncture site.

As can be seen in Table $\mathrm{V}$, the differences in ruminal fluid $\mathrm{pH}$ due to sampling technique found in our experiments were similar to those reported by other authors. $\mathrm{pH}$ values may differ by 0.36 to 1.04 units and this difference is proportional to the intensity of ruminal fermentation. The difference in the concentrations of VFA $(88.94 \mathrm{mmol} / \mathrm{l}$ for puncture and $73.11 \mathrm{mmol} / \mathrm{l}$ for oral tube) reported by Hollberg (1984) for cows with a low production of VFA was 15.83 $\mathrm{mmol} / \mathrm{l}$. In our experiments, the VFA concentrations in the samples collected by puncture exceeded in some animals $130 \mathrm{mmol} / \mathrm{l}$ and the differences relative to the samples collected with oral tube were $30.52,49.68,37.02$, and 50.48 for Groups 1, 2, 3, and 4, respectively.

It is evident that, when appropriate, tests on ruminal fluid samples collected by percutaneous puncture can complete the information on ruminal fermentation processes. Sampling of ruminal fluid by puncture of the caudoventral ruminal sac is an easy and safe procedure. Complications due to puncture were observed in three cows. Two of them developed local inflammatory reactions which disappeared within a few days after topical treatment with iodine tincture. Pregnant uterus was accidentally punctured in the third cow, but no complications developed from this injury. Possible risks of this technique can be minimised by strict observation of principles of good surgical practice. Generally, this method can be recommended for individual cases in which such completion is necessary considering the results of tests of orally collected samples.

\section{Srovnávací studie vzorků bachorové tekutiny získaných odběrem sondou per os nebo přímou punkcí kaudoventrálního vaku bachoru}

U čtyř skupin vysokoužitkových dojnic byly provedeny souběžně odběry bachorové tekutiny sondou per os a přímo jehlou perkutanně z kaudoventrálního vaku bachoru. Byly sledovány základní parametry metabolického profilového testu bachorové tekutiny: $\mathrm{pH}$, celková acidita, amoniak, počet nálevníků, těkavé mastné kyseliny celkově i proporcionálně. Vyšetřením bachorové tekutiny byly získány statisticky významné $(P \leq 0,05)$ rozdíly u dojnic s nižší užitkovostí, denním nádojem v průměru18 $1 \mathrm{u}$ pH 6,74 odběrem per os a 6,23 při odběru perkutánním, celkové aciditě 17,1 při odběru per os a 24,7 při odběru perkutánním a celkové hodnotě TMK 101,18 mmol/l při odběru per os a $131,70 \mathrm{mmol} / \mathrm{l}$ při odběru perkutánním. Statisticky vysoce významné $(P \leq 0,01)$ rozdíly v metabolickém profilu bachorové tekutiny byly zjištěny u dojnic s vysokou užitkovostí 241 a 381 průměrného denního nádoje, u pH 6,95 při odběru per os a 6,24 při odběru perkutánním a 7,00 při odběru per os a 6,21 při odběru perkutánním, celkové aciditě 13,2 při odběru per os a 22,2 při odběru perkutánním a 12,6 při odběru per os a 25,2 při odběru perkutánním, u celkových těkavých mastných kyselin 99,23 $\mathrm{mmol} / \mathrm{l}$ u odběru per os a $136,25 \mathrm{mmol} / \mathrm{l} \mathrm{u}$ odběru perkutánním a $89,66 \mathrm{mmol} / \mathrm{l}$ při odběru per os a 140,14 mmol/l při odběru perkutánním. U skupiny dojnic s průměrným denním nádojem 381 a pufrací krmné dávky hydrogen uhličitanem sodným v dávce $200 \mathrm{~g}$ na den byly rozdíly v pH, celkové aciditě a těkavých mastných kyselinách nejvýraznější, což dokumentuje, že přítomnost 
pufru v krmné dávce ovlivňuje uvedené parametry metabolického profilu bachorové tekutiny. Výsledky ukázaly, že bachorová tekutina získaná punkcí kaudoventrálního vaku bachoru lépe signalizuje úroveň fermentačních procesů v bachoru probíhajících vzhledem $\mathrm{k}$ tomu, že její složení není ovlivňováno množstvím slin, případně pufru, což je charakteristické pro kraniální část bachoru, odkud je odebírána bachorová tekutina sondou per os. Po metodické stránce se ukázalo že odběr bachorové tekutiny provedený punkcí bachoru přes kůži je technicky snadno proveditelný, ale může být doprovázen některými komplikacemi. Rizika je možno minimalizovat přísným dodržováním metodiky odběru a pravidel asepse. Metodu přímého odběru lze doporučit $\mathrm{v}$ individuálních př́ipadech, kdy metodou per os byly získány neočekávané výsledky a kdy je třeba ověřit, že v kaudoventrálním bachorovém vaku se pH a další parametry neodchýlily od fyziologické normy a že nehrozí nebezpečí zdravotních poruch.

\section{Acknowledgment}

This work was supported by the Research Object of the Ministry of Education, Youth and Sports of the Czech Republic (Project No. 16170002/1999)

\section{References}

BRUGERE, H., CHAMPY, R., POLACK, B., ROUSSEAU, Y. 1990: Examen du jus de rumen et surveillance de 1'alimentation des bovis Apport de la titrimétrie. Rec. Méd. Vét. 166: 133-142

COTTYN, B. G., BOUCQUE, CH. V. 1968: Rapid method for the gas-chromatographic determination of volatile fatty acids in rumen fluid. J. Agr. Food Chem. 16: 105-107

DIRKSEN, G. 1975: Eine lenkbare Sonde zur gezielten Entnahme von Pansensaft beim Rind. Tierärztl. Umsch., 30: $367-377$

DIRKSEN, G. 1981: Indigestionen beim Rind. Schnetztor-Verlag GmbH Konstanz, 78 p.

DVOŘÁK, R., HOFÍREK, B., BOUDA, J., DOUBEK, J. 1997: Vyšetření bachorové tekutiny a moči při diagnostice vybraných onemocnění přežvýkavců. Veterinářství 47: 66-68 (Summary in English)

HOFÍREK, B. 1970: Jednoduchá metoda získávání bachorové štávy k diagnostickým účelům u skotu. (A simple method for the collecting of the rumen liquor of cattle for diagnostic purposes) Vet. Med. 15: 89-95 (Summary in English)

HOFÍREK, B., JAGOŠ, P., DVOŘ́́K, R. 1976: A metabolic profile test of rumen fluid and its application in the diagnosis of rumen dysfunction. Reports and Abstracts, 9 International congress on diseases of cattle Paris, 2 , p. 659-664

HOFÍREK, B., HAAS, D. 2000: Metody odběru a význam vyšetření bachorové tekutiny u vysokoužitkových dojnic. Sborník přednášek 8. Mezinárodní konference „Aktuální problémy šlechtění, chovu, zdraví a produkce skotu." Scientific Pedagogical Publishing, České Budějovice, 231-232

HOFÍREK B., HAAS, D. 2000: Metody odběru bachorové tekutiny a jejich vliv na složení bachorové tekutiny u vysokoužitkových dojnic. Zborník prednášok z II. Stredoeurópskeho bujatrického kongresu Vysoké Tatry, p. $122-124$.

HOFÍREK B., HAAS D. 2000: Odběr bachorové tekutiny punkcí bachoru. Veterinářství 50: 135 - 138 (Summary in English)

HOLLBERG, W. 1984: Vergleichende Untersuchungen von mittles SCHAMBYE-SORENSEN-Sonde oder durch Punktion kaudoventralen Pansensack gewonnenen Pansensaftproben. Dtsch. tierärztl. Wschr. 91: 317-320

LEBEDA, M., BUŠ, PŘIKRYLOVÁ, J. 1981: Nástavec k Thygesenově sondě pro čistý odběr bachorové tekutiny $\mathrm{k}$ diagnostickým účelům. Veterinářství 31: 419-421

POLACK, B., PERRIN, G. 1989: Mise au point d'une nouvelle methode de prelevement de jus de rumen par ponction abdominale chez les ruminants. Bull. Soc. Vét. Prat. de France, 73: 503-507

POUNDEN, W. D. 1954: Rumen sampling - a diagnostic aid. Vet. Med. 49: 221-228

ROUSSEAU, J. F., CHAMPY, R., POLACK, B. 1989: Interet pratique dęune nouvelle methode de prelevement du jus de rumen des bovins par voie abdominale. Bull. Soc. Vét. Prat. de France 73: 511-524

SLANINA, L. 1967: Sonda na odběr bachorového obsahu u hovädzieho dobytka a jej využitie v diagnostike a terapii. Veterinářství 17: 171 - 172

SORENSEN, V., SCHAMBYE, P. 1955: Apparatur til udtagelse udtagelse of vomindhold. Medlemsbl. Danske dyrlaegeforen. 38: 60 - 63

YONOV, P. S., MUCHIN, V. G., SEMUSHKIN, N. R., FEDOTOV, A. I., SHARABIN, I. G. 1957: Laboratornye issledovanija v veterinarnoj kliničeskoj diagnostike. 1 ed. Moscow, Kolos (in Russian), 288 p.

ZAPLETAL, O., HOFÍREK, B. 1971: Vliv intoxikace amoniakem močoviny na některé vlastnosti bachorové tekutiny přežvýkavců. (The influence of intoxication with urea ammonia on some properties of ruminal liquor of ruminants) Vet. Med. (Praha) 16: 367-375 (Summary in English) 